Nr 3(66), 2020, s. 261-276

https://doi.org/10.12797/Politeja.17.2020.66.18

Krzysztof KOŹBIAŁ (D)

Uniwersytet Jagielloński

krzysztof.kozbial@uj.edu.pl

\title{
ZNACZENIE EUROSCEPTYCYZMU NA SCENIE POLITYCZNEJ REPUBLIKI CZESKIEJ
}

\section{UWARUNKOWANIA I KONSEKWENCJE}

ABSTRACT The Importance of Euroscepticism on the Political Scene of the Czech Republic. Conditions and Consequences

Czech society is one of the most eurosceptic in the European Union. One of the reasons is a low degree of trust in authority (government, parliament) in general, also at the supranational level. Consequently, Czech political parties have eurosceptic slogans in their programs that do not prevent voters from supporting them, both in the elections to the Czech and European Parliaments. The political system is dominated by parties presenting the so-called „soft euroscepticism" (according to Taggart's and Szczerbiak's approach), such as: Action of Dissatisfied Citizens (ANO 2011), Civic Democratic Party (ODS) or Communist Party of Bohemia and Moravia (KSČM). In the 2017 election, they received a total of almost $50 \%$ of the vote. However, euroscepticism is not a threat to the Czech presence in the EU. Extremely eurosceptic parties do not enjoy great public support.

Keywords: Euroscepticism, Czech Republic, political system of the Czech Republic, Vaclav Klaus, Czexit, Czech Republic in the EU

Słowa kluczowe: eurosceptycyzm, Republika Czeska, system polityczny Czech, Vaclav Klaus, Czexit, Czechy w UE 
$\mathrm{E}$ urosceptycyzm jest zjawiskiem występującym praktycznie we wszystkich państwach członkowskich Unii Europejskiej (UE). Kryzysy w UE nie przyczyniają się do jego ograniczenia. Często przybiera on formę wzrastającego poparcia dla ugrupowań populistycznych, zarówno po prawej, jak i po lewej stronie sceny politycznej. Ugrupowania te nierzadko szukają prostego przekazu, obwiniając UE, „Brukselę”, za różnego rodzaju problemy w swoich państwach.

Republika Czeska jest przykładem kraju, w którym tego rodzaju postawy były i są zauważalne. Wprawdzie nie przybrały one jak dotąd form radykalnych, niemniej jednak dostrzegalne są ugrupowania próbujące budować swą pozycję na scenie politycznej w oparciu m.in. o krytykę UE czy członkostwa Czech w tej organizacji.

Hipoteza badawcza sprowadza się do założenia, iż stosunkowo sceptyczne nastawienie społeczeństwa czeskiego do procesu integracji kontynentu pozwala na istnienie w czeskim systemie partyjnym ugrupowań eurosceptycznych. Nie są one jednak na tyle silne, aby odgrywać dominującą rolę, ani na tyle radykalne, by zagrażać członkostwu państwa w UE.

Celem artykułu jest przede wszystkim wskazanie odpowiedzi na następujące pytania:

1) Jakie są ugrupowania eurosceptyczne na czeskiej scenie politycznej? ${ }^{1}$

2) Co powoduje tego rodzaju postawy?

3) Jaka może być przyszłość tych partii w systemie politycznym państwa?

W artykule wykorzystano metody badawcze typowe dla badań politologicznych: analizę systemową, analizę treści źródeł (w szczególności danych statystycznych) a także, w ograniczonym stopniu, metodę analizy historycznej i metodę prognostyczną.

\section{POJĘCIE EUROSCEPTYCYZMU}

Eurosceptycyzm, jak wiele zjawisk i postaw z obszaru nauk społecznych i humanistycznych, nie jest definiowany w sposób jednorodny, nie znajdziemy więc jednej, ogólnie akceptowanej w tychże naukach definicji. Zasadniczo wyróżnia się definiowanie biorące pod uwagę poziom sprzeciwu wobec procesu integracji Starego Kontynentu albo powody kwestionowania tegoż procesu.

Przyjmuje się, że określenie „eurosceptycyzm” zostało przyjęte w połowie lat 80 . XX w. dla postaw niechętnych wobec integracji europejskiej². Nie oznaczało to jednak

Z powodu ograniczeń objętościowych artykułu autor skupił się jedynie na partiach obecnych w Izbie Poselskiej Republiki po 1993 r. lub takich, które uzyskały sukces w wyborach do Parlamentu Europejskiego (wybór swoich przedstawicieli do tegoż). Na temat mniejszych partii, stosunkowo licznych, lecz „kanapowych”, zob. m.in.: V. Havlík, Euroskepticismus a krajně pravicové strany v České republice, [online] http://casopis.rexter.cz/01-2007/rexter_01_2007-4.pdf, 22 I 2017.

2 W literaturze przedmiotu przyjął się pogląd, iż określenie to zostało użyte po raz pierwszy w 1986 r. w dzienniku „The Times”. Oxford English Dictionary opisywał eurosceptycyzm jako postawę nieentuzjastyczną wobec rozrostu władzy UE. A. Moroska, Prawicowy populizm a eurosceptycyzm (na 
najczęściej negowania całego procesu, lecz jego poszczególnych aspektów. Z czasem podjęto próbę systematyki tego zjawiska.

W publikacjach z końca lat 90. autorstwa Paula Taggarta, który jako jeden z pierwszych prowadził badania nad eurosceptycyzmem, odnaleźć można definicję sprowadzającą go do warunkowej i stanowczej, catkowitej opozycji wobec procesu integracji europejskiej ${ }^{3}$ W tej próbie opisu widoczne jest szerokie podejście autora do zagadnienia, nieprecyzujące granicy między warunkowością a stanowczością.

Z czasem, szczególnie w chwili decydowania o rozszerzeniu UE na wschód, podjęto szersze badania na temat systemów partyjnych nie tylko zachodniej, lecz także środkowej części kontynentu. W konsekwencji zaproponowano podział na twardy i miękki eurosceptycyzm. Do pierwszej grupy zaliczano partie przeciwne zarówno integracji kontynentu, jak i UE jako takiej, co mogło przejawiać się np. optowaniem za wystąpieniem z organizacji. Z kolei przedstawiciele nurtu miękkiego nie byli przeciwnikami integracji, lecz wysuwali zastrzeżenia co do różnych jej aspektów ${ }^{4}$. $Z$ pewnością nie był to podział mający zastosowanie w każdej sytuacji, wobec każdego podmiotu politycznego, lecz dokonywał czytelnego podziału niejednolitego przecież zjawiska.

Jeszcze dalej idącą fragmentację postaw zaproponowali Petr Kopecký i Cas Mudde, wyliczając zachowania eurooptymistyczne, europesymistyczne, a następnie na tej podstawie - euroentuzjastyczne, eurosceptyczne, europragmatyczne i europrzeciwne 5 . Szczegółową, sześciostopniową typologię zaproponował Chris Flood, zaczynając od europrzeciwników, przez rewizjonistów, minimalistów, gradualistów, reformistów, na maksymalistach kończąc ${ }^{6}$.

W polskiej literaturze na ten temat warto zwrócić uwagę na propozycję Krzysztofa Zuby, sprowadzającą się do wyróżnienia trzech rodzajów postaw eurosceptycznych: eurosceptycyzmu przeciwstawiającego się integracji, eurorealizmu jako postawy ambiwalentnej oraz euroentuzjazmu, a więc wsparcia dla integracji ${ }^{7}$. Podsumowanie zróżnicowania podejść badawczych, zauważalne w próbach definicji tego zjawiska, przedstawiono w poniższej tabeli.

przyktadzie Listy Pima Fortuyna w Holandii i Ligi Polskich Rodzin w Polsce), Wrocław 2010, s. 57, Acta Universitatis Wratislaviensis, nr 3230.

3 P. Taggart, A Touchstone of Dissent: Euroscepticism in Contemporary Western European Party Systems, „European Journal of Political Research” 1998, Vol. 33, nr 3, s. 366.

4 P. Taggart, A. Szczerbiak, Parties, Positions and Europe: Euroscepticism in the EU Candidate States of Central and Eastern Europe, Brighton 2001, s. 10, Sussex European Institute Working Paper, 46, [online] https://www.sussex.ac.uk/webteam/gateway/file.php?name=sei-working-paper-no-46.pdf\&site $=266$, 25 I 2020.

5 P. Kopecký, C. Mudde, Two Sides of Euroscepticism. Party Positions on European Integration in East Central Europe, „European Union Politics” 2002, Vol. 3, nr 3, s. 300-303.

6 C. Flood, Euroscepticism: A Problematic Concept, UACES 32 ${ }^{\text {nd }}$ Annual Conference, Belfast, 2-4 IX 2002, [online] http://uaces.org/documents/papers/0201/flood.pdf, 25 I 2020.

7 K. Zuba, Polski eurosceptycyzm i eurorealizm, Opole 2006, s. 55, Studia i Monografie - Uniwersytet Opolski, nr 367. 
Tab. 1. Postawy eurosceptyczne w ujęciu badaczy problemu

\begin{tabular}{|c|c|c|c|c|c|c|}
\hline Autorzy & \multicolumn{3}{|c|}{ Zwolennicy integracji } & \multicolumn{3}{|c|}{ Przeciwnicy integracji } \\
\hline $\begin{array}{c}\text { Paul Taggart, } \\
\text { Aleks Szczerbiak }\end{array}$ & \multicolumn{3}{|c|}{ miękki eurosceptycyzm } & \multicolumn{3}{|c|}{ twardy eurosceptycyzm } \\
\hline $\begin{array}{l}\text { Petr Kopecký, } \\
\text { Cas Mudde }\end{array}$ & \multicolumn{2}{|c|}{ euroentuzjaści } & eurosceptycy & \multicolumn{2}{|c|}{ europragmatycy } & europrzeciwnicy \\
\hline Chris Flood & $\begin{array}{l}\text { maksyma- } \\
\text { liści }\end{array}$ & reformiści & gradualiści & $\begin{array}{l}\text { minima- } \\
\text { liści }\end{array}$ & $\begin{array}{c}\text { rewizjo- } \\
\text { niści }\end{array}$ & $\begin{array}{l}\text { europrze- } \\
\text { ciwnicy }\end{array}$ \\
\hline Krzysztof Zuba & \multicolumn{2}{|c|}{ euroentuzjazm } & \multicolumn{2}{|c|}{ eurorealizm } & \multicolumn{2}{|c|}{ eurosceptycyzm } \\
\hline
\end{tabular}

Źródło: opracowanie własne.

Istotne w postawach eurosceptycznych są także motywy. Zwrócił na nie uwagę m.in. Søren Riishøj, który uznał, że można pod tym względem wyróżnić trzy typy zachowań partii ${ }^{8}$. Po pierwsze, ugrupowania najbardziej radykalne podejmują krytykę procesu integracji z pozycji nacjonalistycznych, najczęściej prawicowych, uznając, że próba tworzenia czegoś na kształt europejskiego superpansstwa będzie prowadziła do likwidacji państw narodowych. Po drugie, niektóre partie podejmują określone ramy krytyki (np. sprzeciw wobec brukselskiej biurokracji czy niedostatku procedur demokratycznych). Po trzecie, partie lewicowe, względnie radykalnie lewicowe, zwracają uwagę na rzekomo wrogie nastawienie procesu integracji do społeczeństw, zarzucając temu projektowi ostrze kapitalistyczne.

Wreszcie warto również zwrócić uwagę na podział na eurosceptycyzm publiczny, wyrażany w czasie referendów, wyborów czy sondaży, oraz partyjny, ujawniający się poprzez włączanie tego rodzaju sloganów do programów poszczególnych ugrupowań politycznych ${ }^{9}$. Oba są zauważalne w analizie sceny politycznej Republiki Czeskiej.

\section{EUROSCEPTYCYZM I JEGO PRZEJAWY NA SCENIE POLITYCZNEJ REPUBLIKI CZESKIEJ}

Do ruchów o charakterze eurosceptycznym najczęściej zaliczane są partie radykalne, znajdujące się po obu stronach skali prawica-lewica. Zależność tę już na początku wieku opisywał Nick Sitter ${ }^{10}$. Co istotne, wiązano to z byciem ugrupowaniem opozycyjnym, nierzadko antysystemowym. Tendencje tego rodzaju wśród partii peryferyjnych

8 S. Riishøj, Europeanisation and Euro-scepticism. Experience from Poland and Czech Republic, "Central European Political Studies Review” 2004, Vol. 6, nr 4, [online] https://journals.muni.cz/cepsr/article/view/4051/5269, 24 I 2020.

$9 \quad$ N. Styczyńska, Więcej czy mniej Europy? Unia Europejska i integracja europejska w dyskursie polskich partii politycznych, Kraków 2018, s. 24.

10 N. Sitter, Opposing Europe. Euro-scepticism, Opposition and Party Competition, Brighton 2002, Sussex European Institute Working Paper, 56, [online] https://www.sussex.ac.uk/webteam/gateway/file. php?name=sei-working-paper-no-56.pdf\&site=266, 20 I 2020. 
analizowali także Liesbet Hooghe, Gary Marks i Carole J. Wilson ${ }^{11}$. Nie zawsze eurosceptycyzm był głównym punktem programów tych ruchów, najczęściej stanowił jeden z przywoływanych argumentów.

Republika Czeska nieco odbiega od tego wzorca. Wprawdzie i tu uformowały się ugrupowania o charakterze skrajnym, negujące konieczność integracji Europy czy też członkostwo Czech w UE, lecz nigdy nie miały one większego wpływu na scenę polityczną. Hasła eurosceptyczne głosiło za to ugrupowanie współrządzące państwem.

System partyjny Republiki Czeskiej zaczął się kształtować, jeszcze gdy istniała Czechosłowacja. W chwili upadku komunizmu przyjął formę jednolitego frontu antykomunistycznego, który jednak uległ szybkiej dekompozycji. Z tej formacji wykształciła się prawicowa Obywatelska Partia Demokratyczna (Občanská demokratická strana, ODS $)^{12}$, która stała się z czasem partią eurosceptyczną. Do 1998 r. oraz w latach 2006-2013 ugrupowanie to współtworzyło koalicję rządzącą. Daleko idący wpływ na jego stanowisko wywarł jego przewodniczący, późniejszy prezydent (2003-2013) Václav Klaus, o czym będzie mowa w dalszej części rozważań.

Obywatelska Partia Demokratyczna akceptowała pozytywny wpływ integracji głównie w sferze gospodarki, szczególnie w liberalizacji handlu. Za idealną formę współpracy uznawano wręcz strefę wolnego handlu (np. EFTA). Nie przeszkadzało to w postępach rozmów z Brukselą na temat członkostwa Republiki w UE, prowadzonych przez rząd ODS.

Po utracie władzy w 1998 r. na rzecz Czeskiej Partii Socjaldemokratycznej (Česká strana sociálně demokratická, ČSSD) ODS się zradykalizowała. W 2001 r. jej czołowi politycy ogłosili dokument programowy: Manifest czeskiego eurorealizmu ${ }^{13}$. Głoszono w nim, ze wejście do UE będzie stanowiło najrozleglejszy przykład dobrowolnego oddania suwerenności państwowej na rzecz organów ponadnarodowych. Wątpliwości wyrażano również w stosunku do całości integracji europejskiej, podkreślając niski stopień identyfikacji społecznej z koncepcją, jak to określano, europaństwa. Krytycznie odnoszono się też do idei federalizacji Europy oraz roli Niemiec w tym procesie.

Ugrupowanie Klausa można zatem zaliczyć do przedstawicieli miękkiego eurosceptycyzmu, którzy nie kwestionowali koncepcji współpracy gospodarczej państw europejskich, lecz byli przeciwni zbyt bliskim związkom politycznym. Wspomniany Manifest byłby więc początkiem eurosceptycznych postaw w ugrupowaniach istotnych dla systemu partyjnego Czech. Kampania przed wyborami parlamentarnymi w $2002 \mathrm{r}$. była pierwszą, w której tematyka stanowisk wobec UE stała się istotna. Należy to także wiązać ze zbliżającym się wówczas referendum akcesyjnym. Obywatelska Partia

11 L. Hooghe, G. Marks, C.J. Wilson, Does Left/Right Structure Party Positions on European Integration?, [w:] European Integration and Political Conflict, red. G. Marks, M. R. Steenbergen, Cambridge 2004, s. $120-140$.

12 K. Koźbial, The Party System of the Czech Republic, [w:] Joint Second Cycle Degree in International Relations: Europe in the Visegrad Perspective. On-line Reader, red. G. Pożarlik, Kraków 2014, s. 131-132, https://visegradstudies.files.wordpress.com/2015/01/visegrad-reader-2014_pr.pdf, 24 I 2020.

13 J. Zahradil, P. Plecitý, P. Adrián, M. Bednár̆, Manifest českého eurorealismu, [online] https://www.ods. $\mathrm{cz} /$ docs/dokumenty/zahradil-manifest.pdf, 24 I 2020. 
Demokratyczna funkcjonuje w systemie partyjnym Czech do dziś, nie odgrywa jednak większej roli. Jej program ciągle zawiera elementy miękkiego eurosceptycyzmu, choć przed wyborami do Parlamentu Europejskiego (PE) w 2019 r. wyraźnie podkreślano, że nie istnieje alternatywa dla czeskiego członkostwa w $\mathrm{UE}^{14}$.

Ugrupowaniem bez większej roli, choć obecnym w parlamencie po wyborach w latach 1992 i 1996 (po 1998 r. już poza legislatywą), było radykalne, prawicowe Zjednoczenie dla Republiki - Republikańska Partia Czechosłowacji (Sdružení pro republiku - Republikánská strana Československa, SPR-RSČ) ${ }^{15}$. Zaliczano je do twardego odłamu eurosceptycyzmu, gdyż odrzucało cały proces integracji, występując zdecydowanie przeciw członkostwu Czech w UE, przede wszystkim z powodu rzekomego zagrożenia utratą niezależności i suwerenności. Pozostałe filary polityki zagranicznej kreślonej przez SPR-RSČ stanowiły sprzeciw wobec wstąpienia do NATO i widoczne ostrze antyniemieckie. Wyraźny wpływ na profil partii wywierał kontrowersyjny i wyrazisty przewodniczący - Miroslav Sládek ${ }^{16}$. Obecnie jest to ugrupowanie o marginalnym znaczeniu, choć bierze udział w elekcjach.

Eurosceptyczne elementy podkreślała również - czyni to zresztą także obecnie Komunistyczna Partia Czech i Moraw (Komunistická strana Čech a Moravy, KSČM), będąca następczynią Komunistycznej Partii Czechosłowacji (Komunistická strana Československa, KSČ). To ugrupowanie o charakterze lewicowym jest obecne we wszystkich parlamentach niepodległej Republiki Czeskiej, choć przez długi czas w praktyce izolowane. Od 2018 r. partia wspiera obecny rząd premiera Andreja Babiša, choć żaden jej przedstawiciel nie wszedł w jego skład. W latach 90. i na początku wieku komuniści mieli ambiwalentny stosunek do Unii; akceptowali jej istnienie, jednak nie zachęcali swych wyborców do wspierania integracji (np. przed referendum akcesyjnym) ${ }^{17}$. W programie KSČM przed wyborami do PE w 2019 r. zwracano przede wszystkim uwagę na konieczność ograniczenia unijnej biurokracji, potrzebę demokratyzacji organizacji, rewizję traktatu z Lizbony, tworzenie sprawiedliwej, socjalnej Europy i potrzebę opracowania nowego programu gospodarczego dla kontynentu ${ }^{18}$. Tłem dla tych rozważań, o charakterze najczęściej relatywnie ogólnym, jest konieczność równouprawnienia państw członkowskich UE.

Ugrupowaniem reprezentującym miękki eurosceptycyzm byli Niezależni Demokraci (Nezávislí demokraté, ND). I w tym przypadku ważne miejsce zajmował lider ugrupowania - Vladimír Železný. Partia sprzeciwiała się przyjęciu tzw. Konstytucji dla Europy oraz rozwojowi integracji w kierunku federalizacji i państwa ponadnarodowego. Odrzucała też możliwość przyjęcia waluty euro. Jej największym sukcesem było

14 Evropské desatero ODS, [online] https://www.ods.cz/volby2019/program-evropske-desatero, 26 I 2020.

15 K. Koźbial, The Party System..., s. 132.

16 V. Havlík, Česká Republika, [w:] Euroskepticismus a země středni a východni Evropy, red. V. Havlík, P. Kaniok, Brno 2006, s. 76-78, Studie (Sociologicke nakladatelstvi), 41.

17 Odnośnie do wizji polityki zagranicznej tego ugrupowania należy podkreślić, iż domagało się ono rozwiązania NATO i było przeciwnikiem członkostwa Czech w Pakcie.

18 Volebni program KSČM $k$ volbám do EP v roce 2019, [online] https://www.kscm.cz/cs/nase-strana/ program, 20 I 2020. 
uzyskanie dwóch miejsc w PE w wyborach z $2004 \mathrm{r}^{19}{ }^{19} \mathrm{~W}$ późniejszym okresie była partią o marginalnym znaczeniu i nie znalazła uznania w oczach wyborców.

Ugrupowaniem eurosceptycznym był także Świt - Koalicja Narodowa (Úsvit Národní koalice), obecny w czeskim parlamencie w latach 2013-201720. W pewnym sensie kontynuacją działań tej partii jest powstały w 2015 r. ruch Wolność i Demokracja Bezpośrednia (Svoboda a př́má demokracie, SPD). Jego założyciel Tomio Okamura wystąpił wtedy ze Świtu. Oba ugrupowania łączyło przekonanie o konieczności stosowania instrumentów demokracji bezpośredniej w zdecydowanie szerszym niż dotąd stopniu, także w odniesieniu do spraw europejskich.

Úsvit należałoby określić, biorąc pod uwagę typologię, jako miękkich eurosceptyków. Partia sprzeciwiała się centralizacji decyzji w organach ponadnarodowych, których przykładem miały być Komisja Europejska i Parlament Europejski, oraz dotacjom unijnym (uznając, że przyczyniają się przede wszystkim do rozrostu biurokracji). Politycy Świtu opowiadali się za wolnq Europa bez granic dla handlu, ustug, inwestycji $i$ osób $b^{21}$. Zdecydowanie sprzeciwiali się przyjmowaniu uchodźców (jednocześnie podkreślając konieczność ochrony granic).

Z kolei SPD, reprezentowane w obecnej czeskiej Izbie Poselskiej, jest bez wątpienia przedstawicielem twardego nurtu eurosceptycyzmu. Domaga się rozpisania referendum dotyczącego wystąpienia Republiki z UE, pełnej suwerenności państwa, a w swej retoryce często sięga do haseł antyimigranckich. Celem ruchu jest Europa rozumiana jako wolny rynek wymiany handlowej i usługowej, otwarty na przepływ pracowników (w grę wchodzi współpraca z innymi państwami w ramach EFTA) ${ }^{22}$. Wymienione punkty programowe stanowią ważne filary programu SPD w polityce zewnętrznej. W programie widoczne jest też przekonanie o konieczności podjęcia takich ruchów, jakie były udziałem Wielkiej Brytanii w ramach brexitu.

Wreszcie do ugrupowań prezentujących elementy eurosceptyczne należy zaliczyć Akcję Niezadowolonych Obywateli (Akce nespokojených občanů, ANO 2011), utworzoną w 2001 r. przez Andreja Babiša, kontrowersyjnego przedsiębiorcę słowackiego pochodzenia, od 2017 r. premiera Czech. Ugrupowanie to jest zasadniczo pragmatyczne wobec procesu integracji, cechuje je tzw. miękki eurosceptycyzm i niewątpliwie populizm, o czym świadczyły już hasła wyborcze, które pozwoliły mu zaistnieć po raz pierwszy podczas wyborów parlamentarnych w 2013 r., kiedy to swój głos na ANO oddało ponad $18 \%$ wyborców ${ }^{23}$.

Akcja nigdy nie kwestionowała procesu integracji europejskiej, opowiadała się natomiast za wzmocnieniem czeskiego członkostwa w UE, podkreślając w programach

19 V. Havlík, Česká Republika..., s. 78-80. Oprócz Železnego w Parlamencie Europejskiej zasiadła Jana Bobošíková.

20 Partię rozwiązano w $2018 \mathrm{r}$.

21 Program strany, [online] http://www.usvitnarodnikoalice.cz/program-strany/, 26 I 2017.

22 Politický program SPD, [online] http://spd.cz/program/, 27 I 2020.

23 K. Koźbial, System partyjny Republiki Czeskiej, [w:] Europa Środkowa / Central Europe, red. K. Żarna, t. 5, Oświęcim 2016, s. 207-208. 
wyborczych konieczność bycia konstruktywnym i krytycznym wobec organizacji. Niemal klasycznymi argumentami w programie ugrupowania są hasła odbiurokratyzowania Brukseli. Partia opowiada się za koniecznością reformy UE, wzmocnieniem jej konkurencyjności w zglobalizowanym świecie, wsparciem dla wolnego rynku i rozszerzeniem organizacji. Krytyce poddawano m.in. cele sformułowane w programie „Europa 2020”24. W okresie kryzysu migracyjnego w Europie premier Babiš był zdecydowanym przeciwnikiem przyjmowania przez Czechy uchodźców, co także stanowiło istotny przejaw postawy eurosceptycznej.

Wyraźny rys eurosceptyczny, pozwalający mówić o jego twardej odmianie, wykazywała Partia Wolnych Obywateli (Strana svobodných občanů, SSO), obecnie Svobodní, założona w 2009 r. przez Petra Macha, ówczesnego posła do PE, sprzeciwiającego się podpisaniu traktatu lizbońskiego. Partia postulowała wyjście Czech z UE, uznając, że integracja europejska to ślepa uliczka, UE nie da się zreformować, zatem Republika powinna zostać jedynie członkiem EFTA ${ }^{25}$. Svobodní są pod tym względem ugrupowaniem radykalnym. Obecnie nie odgrywają żadnej ważnej roli w systemie partyjnym państwa.

Odnosząc się do zarysowanych wcześniej typologii eurosceptycyzmu, można stwierdzić, że w Czechach w okresie niezależności państwowej istniały i istnieją eurosceptyczne ugrupowania polityczne. Ich podział według typologii Taggarta i Szczerbiaka przedstawiono w poniższej tabeli.

Tab. 2. Partie w Republice Czeskiej reprezentujące „miękki” i „twardy” eurosceptycyzm

\begin{tabular}{|c|c|}
\hline Eurosceptycyzm „miękki” & Eurosceptycyzm „twardy” \\
\hline ODS & SPR-RSČ \\
KSČM & SPD \\
ND & SSO \\
Úsvit & \\
ANO 2011 & \\
\hline
\end{tabular}

Źródło: opracowanie własne. Tabela obejmuje ugrupowania, które po 1993 r. znalazły się w Izbie Poselskiej lub w Parlamencie Europejskim.

Potwierdzeniem znaczenia partii eurosceptycznych były wybory do niższej izby parlamentu Czech i do PE. Bez wątpienia największym poparciem spośród nich cieszyła się początkowo ODS, a w ostatnich wyborach - ANO 2011. Poparcie dla ugrupowań eurosceptycznych w wyborach do wyższej izby czeskiego parlamentu ukazano w tab. 3. Na scenie politycznej niezależnej Republiki Czeskiej są stale obecne ODS i KSČM, ale twardzi eurosceptycy tylko raz, w 1996 r., pokonali próg wyborczy do Izby Poselskiej.

24 Nás program pro volby do Evropského parlamentu, [online] https://www.anobudelip.cz/cs/o-nas/euro volby/detailni-program/, 25 I 2020.

25 Politický program Svobodných, [online] https://web.svobodni.cz/program/politicky-program, 27 I 2017. 
Tab. 3. Poparcie dla partii eurosceptycznych w wyborach do Izby Poselskiej w Czechach od 1993 r. (\%)

\begin{tabular}{|c|c|c|c|c|c|c|c|}
\hline Partia & 1996 & 1998 & 2002 & 2006 & 2010 & 2013 & 2017 \\
\hline ODS & 29,62 & 27,74 & 24,47 & 35,38 & 20,22 & 7,72 & 11,32 \\
\hline KSČM & 10,33 & 11,03 & 18,51 & 12,81 & 11,27 & 14.91 & 7,76 \\
\hline Úsvit & - & - & - & - & - & 6,88 & - \\
\hline SPR-RSČ & 8,01 & - & - & - & - & - & - \\
\hline SPD & - & - & - & - & - & - & 10,64 \\
\hline ANO 2011 & - & - & - & - & - & 18,65 & 29,64 \\
\hline Razem & 47,96 & 38,77 & 42,98 & 48,19 & 31,49 & 48,16 & 59,36 \\
\hline
\end{tabular}

Źródło: opracowanie własne na podstawie www.volby.cz. Podano wyniki ugrupowań, które przekroczyły próg wyborczy w poszczególnych wyborach i zdobyły mandaty.

W przedstawionych wynikach zwraca uwagę fakt, że - biorąc pod uwagę poparcie tylko dla ugrupowań, które dostały się do Izby Poselskiej (zatem przekroczyły pięcioprocentowy próg wyborczy) - poparcie dla tego rodzaju partii jest w Republice Czeskiej stosunkowo wysokie. Podczas ostatnich wyborów w 2017 r. głosowało na nie prawie 60\% wyborców, a w kilku przypadkach było to niemal $50 \%$ głosów.

Wyborcy w Republice Czeskiej byli nie mniej skłonni poprzeć eurosceptyków w wyborach do PE. W 2004 r. partie eurosceptyczne zdobyły aż 17 z 24 miejsc przewidzianych w PE dla Czech (czyli prawie 71\%), w 2014 r. było to jedynie 6 z 21 miejsc (28,6\%), zaś pięć lat później - $13(61,9 \%)^{26}$. Mamy zatem do czynienia ze znaczącym wahaniem poparcia, które przedstawiono w tab. 4 .

Tab. 4. Poparcie dla partii eurosceptycznych w wyborach do Parlamentu Europejskiego w Czechach od 2004 r. (\%)

\begin{tabular}{|c|c|c|c|c|}
\hline Partia & 2004 & 2009 & 2014 & 2019 \\
\hline ODS & 30,04 & 31,45 & 7,67 & 14,54 \\
\hline KSČM & 20,26 & 14,18 & 10,98 & 6,94 \\
\hline ND & 8,18 & - & - & - \\
\hline SSO & - & - & 5,24 & - \\
\hline SPD & - & - & - & 9,14 \\
\hline ANO 2011 & - & - & 16,13 & 21,18 \\
\hline Razem & 58,48 & 45,63 & 40,02 & 51,80 \\
\hline
\end{tabular}

Źródło: opracowanie własne na podstawie www.volby.cz. Podano wyniki ugrupowań, które przekroczyły próg wyborczy w poszczególnych wyborach i zdobyły mandaty.

26 P. Just, Euroskepticismus a euroskeptické strany ve volbách do Evropského parlamentu $2014 v$ ČR a na Slovensku, „Politics in Central Europe. The Journal of the Central European Political Science Association” 2015, Vol. 11, nr 15, s. 116, [online] http://www.politicsincentraleurope.eu/documents/file/Volume\%20 11\%20-\%20Number\%201S\%20-\%20April\%20-\%202015.pdf, 20 I 2020; www.volby.cz, 20 I 2020. 
Należy zaznaczyć, że cztery elekcje do PE cieszyły się bardzo słabym zainteresowaniem wyborców ${ }^{27}$. W zasadzie uzasadnione jest stwierdzenie o ich małej reprezentatywności, niemniej eurosceptykom udało się skutecznie zmobilizować swoich wyborców.

Nie sposób nie zauważyć, że ważny wkład w eurosceptycyzm na czeskiej scenie politycznej miały (i mają) osoby sprawujące urząd prezydenta Republiki Czeskiej. W szczególności należy tu podkreślić znaczenie Václava Klausa, który wielokrotnie określał się jako eurosceptyk, podkreślając przede wszystkim znaczenie elementu gospodarczego w integracji kontynentu. W jednej ze swoich książek Klaus posunął się nawet do stwierdzenia, że we współczesnej Europie mamy do czynienia z ideologia europeizmu, będącą produktem elit, objawiającą się unifikacją, standaryzacją, deficytem demokracji na poziomie unijnym ${ }^{28}$.

Krytycznego nastawienia wobec UE nie kryje także obecny prezydent Miloš Zeman. Nie jest on mimo to zwolennikiem wystąpienia Czech z organizacji. Gdyby jednak miało do tego dojść, taką decyzję mogliby według niego podjąć jedynie czescy obywatele $\mathrm{w}$ referendum ${ }^{29}$. Zeman wspomniał o tym jeszcze przed brytyjskim referendum dotyczącym opuszczenia UE przez Wielką Brytanię. Prezydent określa się jako przeciwnik federalizacji UE, wkraczającej w kompetencje państw członkowskich.

\section{EUROSCEPTYCYZM W CZESKIM SPOŁECZEŃSTWIE}

W 2004 r. Republika Czeska, podobnie jak kilka innych państw postkomunistycznych, stała się członkiem UE. Ostateczną decyzję w tej sprawie obywatele państwa podjęli w referendum, które odbyło się w dniach 13-14 czerwca 2003 r. W głosowaniu wzięło udział ponad 55,2\% uprawnionych; 77,33\% głosowało za wstąpieniem do organiza$\mathrm{cji}^{30}$. Stanowiło to ukoronowanie zabiegów kolejnych czeskich rządów, które - podobnie jak polskie - przez długie lata operowały hasłem „powrotu do Europy”.

Wynik ten zdecydowanie wskazywał na zwycięstwo opcji proeuropejskiej. Nie oznaczało to bynajmniej, iż owo stanowisko bezkrytycznie podzielali wszyscy. Wręcz przeciwnie: na przestrzeni lat dało się zauważyć względnie krytyczną postawę Czechów zarówno wobec integracji, jak i w stosunku do samej UE. Co godne podkreślenia, jeszcze przed referendum społeczeństwo czeskie nie wydawało się przekonane do członkostwa

27 W 2004 r. brało w nich udział 28,3\% uprawnionych, w 2009 - 28,2\%, w 2014 - jedynie 18,2\%, a w $2019-28,7 \%$.

28 V. Klaus, Czym jest europeizm?, przeł. K. Sarna, Warszawa 2008.

29 Zeman: O vystoupeni Česka z EU by méli rozhodnout občanév referendu, 25 II 2016, [online] https:// zpravy.aktualne.cz/domaci/zeman-o-vystoupeni-ceska-z-eu-by-meli-rozhodovat-obcane-v-re/r 06afe0b2dbe911e5807d0025900fea04, 26 II 2016.

30 Referendum o pristoupeni České republiky k Evropské unii konané ve dnech 13.-14.06.2003, [online] http://www.volby.cz/pls/ref2003/re13?xjazyk=CZ, 23 I 2017. Poparcie na podobnym poziomie wyrażone zostało w referendum w Polsce, które odbyło się w dniach 7-8 czerwca 2003 r., przy frekwencji prawie 59\%. 
w UE. Przeważali zwolennicy akcesji, lecz w badaniach opinii najlepszy wynik osiągnęli w lutym 2002 r. (48\% poparcia), podczas gdy trzy lata wcześniej za przystąpieniem do UE było jedynie $35 \%$ (przeciw 16\%, aż 22\% niezdecydowanych) ${ }^{31}$.

Prowadzone od lat badania opinii publicznej dają obraz stosunku społeczeństwa czeskiego do UE i członkostwa w niej Czech, postaw wobec integracji europejskiej jako takiej oraz postrzegania instytucji międzynarodowych, w tym unijnych. Wykorzystane w artykule badania były najczęściej prowadzone przez Centrum Badania Opinii Publicznej (Centrum pro výzkum veřejného mínění, CVVM), będące obecnie częścią Instytutu Socjologii Czeskiej Akademii Nauk.

Od kilkunastu lat badane jest zadowolenie czeskiego społeczeństwa z członkostwa w UE. W kwietniu 2019 r. bardzo zadowolonych z tego faktu było jedynie 6\% ankietowanych, zadowolonych $31 \%$, raczej niezadowolonych $17 \%$, a bardzo niezadowolonych $9 \%^{32}$. Ponad $1 / 3$ pytanych była zatem przynajmniej zadowolona, co jest rezultatem lepszym niż jeszcze kilka lat temu (w latach 2012 i 2016 jedynie $1 / 4$ była zadowolona lub raczej zadowolona, z kolei w latach 2008 i 2009 zadowolonych było $40 \%$ pytanych). Ankietowani niezbyt dużą wagę przywiązują do bycia obywatelami UE: dumnych z tego jest tylko 39\% pytanych, niezbyt lub w ogóle - 50\% ankietowanych.

Wśród negatywnych stron członkostwa Czesi wymieniają przede wszystkim rozrost biurokracji (84\%), nadmierne ograniczenia będące wynikiem stosowania prawa unijnego $(74 \%)$ oraz odpływ wykwalifikowanych pracowników do innych państw członkowskich (72\%). Pozytywne strony według respondentów to: lepsza możliwość studiowania, pracowania i życia w UE (83\%), napływ unijnych dotacji (70\%) i wzrost bezpieczeństwa militarnego $(57 \%)^{33}$.

Występuje korelacja między wiekiem a opiniami na temat członkostwa w UE: starsi respondenci są wyraźnie bardziej sceptyczni. O ile wśród całej populacji 44\% uznaje, że negatywne aspekty integracji przeważają nad pozytywnymi (przeciwne zdanie ma tylko $13 \%$ ankietowanych), o tyle wśród ludzi w wieku powyżej 60 lat 56\% uważa, że negatywne aspekty biorą górę ${ }^{34}$.

Mimo umiarkowanego stopnia zadowolenia z członkostwa w UE ponad połowa (52\%) pytanych ufa (lub raczej ufa) tej organizacji, w 2016 r. było to zaledwie $37 \%$. Wśród unijnych urzędów czy instytucji najmniejszym zaufaniem cieszy się Wysoki Przedstawiciel ds. Wspólnej Polityki Zagranicznej i Bezpieczeństwa, co zapewne

31 V. Havlík, Česká Republika..., s. 64. Istotny wpływ na brak wzrostu akceptacji dla UE miało niewątpliwie niepowodzenie procesu wejścia w życie tzw. Konstytucji dla Europy (referenda odrzucające projekt we Francji i Holandii w 2005 r.).

32 Názory veřejnosti na členství České republiky v Evropské unii - duben 2019, s. 2, [online] https://cvvm. soc.cas.cz/cz/tiskove-zpravy/politicke/mezinarodni-vztahy/4924-nazory-verejnosti-na-clenstvi-ceske-republiky-v-evropske-unii-duben-2019, 28 I 2020.

33 Tamże, s. 5.

34 M. Německý, Česká republika v Evropské unii - Co občané očekávají a čeho se obávají? Výsledky reprezentativního výzkumu, Praha 2016, s. 15. Badania te były finansowane przez Friedrich-Ebert-Stiftung, prowadzono je w ośmiu państwach UE (Czechy, Francja, Hiszpania, Holandia, Niemcy, Włochy, Słowacja i Szwecja). 
wynika z braku wiedzy na jego temat. Większym zaufaniem czeskie społeczeństwo darzy ONZ (63\%) i NATO $(61 \%)^{35}$.

Podczas badań prowadzonych w kwietniu 2019 r. pytano również o postawę wobec integracji europejskiej jako takiej. Wśród wartości, którymi kieruje się UE, respondenci najwyżej cenią demokrację i współpracę (po 66\%) oraz solidarność (56\%). Przekonanie o ich ważności jest wyraźnie wyższe niż w poprzednich latach. Jednak aż 64\% uznaje, że w działaniu organizacji nie odgrywają ważnej roli równość (56\%) czy sprawiedliwość $(53 \%)^{36} .69 \%$ pytanych ocenia, że korzystna byłaby dalsza integracja w ramach poprzednich unii w dziedzinie obronności, 67\% ekologii, a 56\% - gospodarce. Tylko $30 \%$ wierzy jednak w to, że decyzje podejmowane przez UE są zgodne z czeskimi interesami $(65 \% \text { jest przeciwnego zdania })^{37}$. Ankietowani odpowiadali podobnie na pytanie o zgodność tychże decyzji z interesami „zwykłych ludzi”.

Czeski eurosceptycyzm jest szczególnie zauważalny, jeśli chodzi o ewentualne przyjęcie euro - w kwietniu 2019 r. jedynie 20\% pytanych było za takim rozwiązaniem, aż $75 \%$ przeciw $^{38}$. Od 2006 r. europejska waluta ma więcej przeciwników niż zwolenników, przy czym drastyczne różnice w opinii na ten temat są bez zwątpienia pochodną kryzysu finansowego końca pierwszego dziesięciolecia obecnego wieku.

Sceptyczna postawa czeskiego społeczeństwa wiąże się też z niechęcią do przesunięcia podejmowanych decyzji na poziom wspólny (w ramach UE). 42\% uważa, że to Rada Europejska złożona z głów państw mogłaby mieć ewentualnie większy wpływ na podejmowanie decyzji, lecz 56\% wskazuje na czeski rząd, a aż $71 \%$ na obywateli, który mieliby rozstrzygać na drodze referendum ${ }^{39}$.

Niski poziom zaufania wobec instytucji UE można wytłumaczyć generalnie niskim zaufaniem do władzy w ogóle. Jest to zresztą zjawisko typowe dla byłych państw socjalistycznych, a także wschodnich krajów związkowych RFN. Czesi nie ufają nie tylko instytucjom unijnym; 50\% nie ufa własnemu rządowi (ufa mu 46\%), 56\% parlamentowi (poziom zaufania: $38 \%)^{40}$.

Czesi należą bezsprzecznie do społeczeństw UE o najmniejszym zaufaniu do tej organizacji. Według badań przedstawionych przez Eurobarometr w czerwcu 2019 r. UE ufa jedynie 36\% pytanych (gorzej było tylko w przypadku Francji, Grecji i Wielkiej Brytanii), raczej nie ufa 55\% pytanych. Dla porównania w Polsce stopień zaufania

35 Są to dane z kwietnia 2019 r. Di̛véra v evropské a mezinárodní instituce - duben 2019, [online] https://cvvm.soc.cas.cz/cz/tiskove-zpravy/politicke/mezinarodni-vztahy/4922-duvera-v-evropskea-mezinarodni-instituce-duben-2019, 29 I 2020.

36 Hodnocení evropské integrace - duben 2019, s. 2-3, [online] https://cvvm.soc.cas.cz/media/com form2content/documents/c2/a4928/f9/pm190528.pdf, 29 I 2020.

37 Ibidem, s. 4 .

38 Občané o prijietí eura a dopadech členství ČR v EU-duben 2019, s. 4-5, [online] https://cvvm.soc.cas. cz/media/com_form2content/documents/c2/a4932/f9/pm190531.pdf, 29 I 2020.

39 M. Německý, Česká republika..., s. 24. Na większy wpływ Parlamentu Europejskiego wskazało 35\%, a Komisji Europejskiej - 33\% ankietowanych.

40 Divvéra ústavním institucim v lednu 2020, s. 1-2, [online] https://crvm.soc.cas.cz/media/com_form2content/documents/c2/a5114/f9/pi200210.pdf, 29 I 2020. 
wynosił 54\%, największy prezentowali zaś mieszkańcy Litwy - 72\%. Tylko u 29\% pytanych w Czechach obraz UE jest pozytywny, u takiego samego odsetka negatywny. Równocześnie 53\% Czechów widzi przyszłość UE optymistycznie ${ }^{41}$.

Przy niskim stopniu zaufania do unijnych instytucji nie może dziwić dosyć słaba wiara zarówno w UE jako całość, jak i w proces integracji. Jednym z wytłumaczeń, choć zapewne nie jedynym, jest - jak można domniemywać - stosunkowo niski poziom wiedzy o UE. Spadek zaufania jest zjawiskiem postępującym, gdyż w momencie wstępowania Czech do tej organizacji ufało jej prawie $2 / 3$ pytanych; wyższe było też zaufanie do poszczególnych instytucji. Najwyższy stopień nieufności wykazują, podobnie jak w innych badaniach, ludzie starsi oraz wyborcy KSČM i SPD. Głosowanie na te właśnie ugrupowania wydaje się zatem nieprzypadkowe.

Wpływ na postrzeganie UE miały bezsprzecznie zauważalne w ostatnich latach kryzysy. Szczególnie tzw. kryzys migracyjny z 2015 r. umocnił postawy eurosceptyczne w społeczeństwie. Prawie $2 / 3$ pytanych już w 2016 r. uznawało, że Republika Czeska nie powinna przyjmować uchodźców przybywających do Europy, a 30\% wyrażało zgodę na ich warunkowe przyjęcie do momentu, kiedy będą mogli wrócić do kraju pochodze$\mathrm{nia}^{42}$. Do dziś postawy te nie uległy zmianom. Kryzys migracyjny był przy tym uznawany za jedno z najważniejszych zagrożeń dla bezpieczeństwa państwa czeskiego i Europy. Zdanie takie wyrażało ponad $3 / 4$ pytanych, nieco niej (66\%) wskazywało ogólnie na politykę międzynarodową ${ }^{43}$.

\section{PODSUMOWANIE}

Eurosceptycyzm na scenie politycznej Republiki Czeskiej nie jest zjawiskiem nowym. Społeczeństwo czeskie należy bez wątpienia do najbardziej negatywnie nastawionych do UE i integracji spośród 27 państw członkowskich organizacji, czego dowodzą badania opinii publicznej, ale i wspieranie ugrupowań krytycznych, przynajmniej w niektórych wymiarach, wobec UE i integracji. Postrzeganie Unii i jej instytucji nie ulega w ostatnich latach poprawie. Mimo to większość ankietowanych wciąż jest zdania, że Czechy powinny pozostać $\mathrm{w}$ tej organizacji.

Elementy eurosceptyczne są zauważalne w programach i działalności ugrupowań politycznych, choć trudno byłoby sformułować tezę, że nadają ton dyskursowi politycznemu. Co interesujące, owe partie - przede wszystkim te zaliczane do miękkiego nurtu eurosceptycznego - cieszą się stosunkowo wysokim poparciem wśród wyborców. Dotyczy to zarówno wyborów parlamentarnych, jak i elekcji do PE, choć ich frekwencja jest mała i trudno nazwać je reprezentatywnymi.

41 Die öffentliche Meinung in der Europäischen Union. Standard Eurobarometer 91, Frühjahr 2019, s. 6, 10,12, [online] https://ec.europa.eu/commfrontoffice/publicopinionmobile/index.cfm/Survey/ getSurveyDetail/surveyKy/225, 30 I 2020.

42 Postoj české verejnosti k prijimímáni uprchliků - prosinec 2016, s. 2, [online] http://cvvm.soc.cas.cz/me dia/com_form2content/documents/c1/a7644/f3/pm170113.pdf, 26 I 2017.

43 M. Německý, Česká republika..., s. 11. 
Problemy UE zapewne przyczyniają się do dalszego spadku akceptacji tej organizacji w czeskim społeczeństwie. Wykazuje ono daleko idący brak zaufania wobec władzy jako takiej, zarówno na poziomie narodowym (rząd, parlament), jak i ponadnarodowym (instytucje unijne). W konsekwencji elementy eurosceptyczne prezentowane przez poszczególne ugrupowania nie odstręczają wyborców od głosowania na nie. Jednak - co należy zaakcentować - ugrupowania radykalne w swych ocenach (opowiadające się np. za wyjściem Czech z UE) nie zajmują czołowych miejsc na scenie politycznej Republiki.

Pytanie, czy może się to przełożyć na skłonność do głosowania na ugrupowania eurosceptyczne - w szczególności te radykalne - w większym niż dotąd stopniu, pozostaje otwarte. W mojej ocenie obecnie nic na to nie wskazuje. Potencjalni wyborcy w Czechach ciągle są przekonani do głosowania na ugrupowania prezentujące tzw. miękki eurosceptycyzm (np. ANO, ODS, KSČM), bowiem stanowią one ważny czynnik składowy czeskiej sceny partyjnej. W efekcie podczas ostatnich wyborów do Izby Poselskiej trzy wymienione ugrupowania uzyskały bez mała połowę głosów.

\section{BIBLIOGRAFIA}

Die öffentliche Meinung in der Europäischen Union. Standard Eurobarometer 91, Frühjahr 2019, [online] https://ec.europa.eu/commfrontoffice/publicopinionmobile/index.cfm/Survey/ getSurveyDetail/surveyKy/225.

Di̊vèra ústavnim institucim v lednu 2020, [online] https://cvvm.soc.cas.cz/media/com_form2content/documents/c2/a5114/f9/pi200210.pdf.

Di̛vèra v evropské a mezinárodní instituce - duben 2019, [online] https://cvvm.soc.cas.cz/cz/ tiskove-zpravy/politicke/mezinarodni-vztahy/4922-duvera-v-evropske-a-mezinarodni-instituce-duben-2019.

Evropské desatero ODS, [online] https://www.ods.cz/volby2019/program-evropske-desatero.

Flood C., Euroscepticism: A Problematic Concept, UACES $32^{\text {nd }}$ Annual Conference, Belfast, 2-4 IX 2002, [online] http://uaces.org/documents/papers/0201/flood.pdf.

Havlík V., Česká Republika, [w:] Euroskepticismus a zemé středni a východni Evropy, red. V. Havlík, P. Kaniok, Brno 2006, Studie (Sociologicke nakladatelstvi), 41.

Havlík V., Euroskepticismus a krajně pravicové strany v České republice, [online] http://casopis. rexter.cz/01-2007/rexter_01_2007-4.pdf.

Hodnoceni evropské integrace - duben 2019, [online] https://cvvm.soc.cas.cz/media/com form2content/documents/c2/a4928/f9/pm190528.pdf.

Hooghe L., Marks G., Wilson C.J., Does Left/Right Structure Party Positions on European Integration? [w:] European Integration and Political Conflict, red. G. Marks, M.R. Steenbergen, Cambridge 2004, https://doi.org/10.1177/001041402236310.

Just P., Euroskepticismus a euroskeptické strany ve volbách do Evropského parlamentu 2014 v ČR a na Slovensku, „Politics in Central Europe. The Journal of the Central European Political Science Association" 2015, Vol. 11, nr 15, [online] http://www.politicsincentraleurope.eu/ documents/file/Volume\%2011\%20-\%20Number\%201S\%20-\%20April\%20-\%202015.pdf. 
Klaus V., Czym jest europeizm?, przeł. K. Sarna, Warszawa 2008.

Kopecký P., Mudde C., Two Sides of Euroscepticism. Party Positions on European Integration in East Central Europe, „European Union Politics” 2002, Vol. 3, nr 3, https://doi.org/10.117 7/1465116502003003002.

Koźbiał K., System partyjny Republiki Czeskiej, [w:] Europa Środkowa / Central Europe, red. K. Żarna, t. 5, Oświęcim 2016.

Koźbiał K., The Party System of the Czech Republic, [w:] Joint Second Cycle Degree in International Relations: Europe in the Visegrad Perspective. On-line Reader, red. G. Pożarlik, Kraków 2014, https://visegradstudies.files.wordpress.com/2015/01/visegrad-reader-2014_pr.pdf.

Moroska A., Prawicowy populizm a eurosceptycyzm (na przyktadzie Listy Pima Fortuyna w Holandii i Ligi Polskich Rodzin w Polsce), Wrocław 2010, Acta Universitatis Wratislaviensis, nr 3230.

Náš program pro volby do Evropského parlamentu, [online] https://www.anobudelip.cz/ cs/o-nas/eurovolby/detailni-program/.

Názory veřejnosti na členství České republiky v Evropské unii - duben 2019, [online] https:// cvvm.soc.cas.cz/cz/tiskove-zpravy/politicke/mezinarodni-vztahy/4924-nazory-verejnosti-na-clenstvi-ceske-republiky-v-evropske-unii-duben-2019.

Německý M., Česká republika v Evropské unii - Co občané očekávají a čeho se obávají? Výsledky reprezentativniho výzkumu, Praha 2016.

Občané o prijetí eura a dopadech členství $\check{C} R v E U$-duben 2019, [online] https://cvvm.soc.cas. cz/media/com_form2content/documents/c2/a4932/f9/pm190531.pdf.

Politický program SPD, [online] http://spd.cz/program/.

Politický program Svobodných, [online] https://web.svobodni.cz/program/politicky-program.

Postoj české veŕejnosti k prijizimáni uprchlikü - prosinec 2016, [online] http://cvvm.soc.cas.cz/ media/com_form2content/documents/c1/a7644/f3/pm170113.pdf.

Program strany, [online] http://www.usvitnarodnikoalice.cz/program-strany/.

Referendum o pristoupeni České republiky k Evropské unii konané ve dnech 13.-14.06.2003, [online] http://www.volby.cz/pls/ref2003/re13?xjazyk=CZ.

Riishøj S., Europeanisation and Euro-scepticism. Experience from Poland and Czech Republic, „Central European Political Studies Review” 2004, Vol. 6, nr 4, [online] https://journals. muni.cz/cepsr/article/view/4051/5269.

Sitter N., Opposing Europe. Euro-scepticism, Opposition and Party Competition, Brighton 2002, Sussex European Institute Working Paper, 56, [online] https://www.sussex.ac.uk/webteam/ gateway $/$ file.php? name $=$ sei-working-paper-no-56.pdf\&site $=266$.

Styczyńska N., Więcej czy mniej Europy? UE i integracja europejska w dyskursie polskich partii politycznych, Kraków 2018.

Taggart P., A Touchstone of Dissent: Euroscepticism in Contemporary Western European Party Systems, „European Journal of Political Research” 1998, Vol. 33, nr 3, https://doi. org/10.1111/1475-6765.00387.

Taggart P., Szczerbiak A., Parties, Positions and Europe: Euroscepticism in the EU Candidate States of Central and Eastern Europe, Brighton 2001, Sussex European Institute Working Paper, 46, [online] https://www.sussex.ac.uk/webteam/gateway/file.php?name=sei-workingpaper-no-46.pdf\&site $=266$. 
Volebni program KSČM $k$ volbám do EP v roce 2019, [online] https://www.kscm.cz/cs/nasestrana/program.

Zahradil J., Plecitý P., Adrián P., Bednář M., Manifest českého eurorealismu, [online] https:// www.ods.cz/docs/dokumenty/zahradil-manifest.pdf.

Zeman: O vystoupeni Česka $z$ EU by mèli rozhodnout občanév referendu, 25 II 2016, [online] https://zpravy.aktualne.cz/domaci/zeman-o-vystoupeni-ceska-z-eu-by-meli-rozhodovatobcane-v-re/r 06afe0b2dbe911e5807d0025900fea04.

Zuba K., Polski eurosceptycyzm i eurorealizm, Opole 2006, Studia i Monografie - Uniwersytet Opolski, nr 367.

Dr hab. Krzysztof KOŹBIAŁ - dr hab. nauk o polityce w zakresie systemów politycznych, profesor Uniwersytetu Jagiellońskiego. Adiunkt w Instytucie Europeistyki Uniwersytetu Jagiellońskiego w Krakowie. Jego zainteresowania naukowe wiążą się z systemami politycznymi, w szczególności państw niemieckojęzycznych i środkowoeuropejskich, procesem integracji europejskiej (szczególnie rozszerzeniem UE w kierunku Bałkanów), jak również polityką zewnętrzną i wewnętrzną państw Europy Środkowej. Autor i redaktor ponad 110 publikacji naukowych (monografii, artykułów naukowych i rozdziałów w monografiach). 